KONSEP SPIRITUALITAS DAN RELIGIUSITAS ( SPIRITUAL AND RELIGION) DALAM KONTEKS KEPERAWATAN PASIEN DIABETES MELITUS TIPE 2
NURSCOPE

Jurnal Keperawatan dan

Pemikiran IImiah

Ardian, I (2016). Konsep Spiritualitas Dan Religiusitas ( Spiritual And Religion) Dalam Konteks Keperawatan Pasien Diabetes Melitus Tipe 2. Nurscope. Jurnal Keperawatan dan Pemikiran Ilmiah. 2 (5). 1-9

\author{
Iwan Ardian ${ }^{1}$
}

Fakultas IImu Keperawatan, Universitas Islam Sultan Agung Semarang

\begin{abstract}
ABSTRAK
Diabetes adalah salah satu gangguan kesehatan yang bersifat kronis dan paling berdampak psikologis pada pasien dan sering dikaitkan dengan dengan beberapa gangguan kejiwaan. Pasien dengan diabetes dua kali lebih beresiko memiliki status kecemasan,depresi dan masalah psikologis yang serius. Tekanan psikologis pasien yang mengalami diabetes militus sering dikaitkan dengan kesejahteraan spiritual dan kepatuhan religus. Terbatasnya informasi yang berkaitan dengan spiritualitas pasien dan keluarga serta adanya pandangan yang berbeda dalam menafsirkan spiritualitas dan religiusitas menjadikan kurang optimal dalam meningkatkan kesejahteraan spiritual pasien yang pada akhirnya dapat membantu pasien meningkat kualitas hidupnya. spiritualitas dan religiusitas dapatlah dibedakan bagaimana pasien diabetes yang mengalami masalah spiritualitas dan pasien yang mengalami maslah religiusitas, karena keduanya memiliki konsep dan dimensi yang berbeda.
\end{abstract}

Kata Kunci : Diabetes Militus, Religiusitas, Spiritualitas.

\title{
SPIRITUAL AND RELIGION CONCEPT IN NURSING FOR DIABETIC MELITUS PATIENTS
}

\section{ABSTRACT}

Diabetes is one of the chronic health problems and the psychological impact on the patient and is often associated with with several psychiatric disorders. Patients with diabetes were twice as likely to have status anxiety, depression and serious psychological problems. The psychological pressure of patients with diabetes mellitus often associated with the spiritual welfare and compliance religion. The limited information relating to the spirituality of the patient as well as their different views in interpreting spirituality and religion make less than optimal in increasing the spiritual wellbeing of patients that can ultimately help patients increase their quality of life. spirituality and religion how it can be distinguished patients with diabetes who have problems of spirituality and religion of patients who experienced an issue, because both have different concepts and dimensions.

Keywords: Diabetes mellitus, Religion, Spirituality.

Corresponding Author:

Iwan Ardian ${ }^{1}$, Fakultas IImu Keperawatan Universitas Islam Sultan Agung, Jalan Raya Kaligawe Km 4, Semarang, Jawa Tengah, Indonesia, Kode pos 50112

\section{PENDAHULUAN}

Tumbuh kembang manusia adalah merupakan proses yang berjalan seumur hidup yang ditandai dengan pola pertumbuhan dan perkembangan fisik, psikis dan variasi interaksi yang meliputi semua dimensi kebutuhan manusia. Dimensi pertumbuhan dan perkembangan meliputi dimensi fisiologis, psikologis, sosial, kulktural dan spiritual. Setiap individu akan mengalami pola tumbang yang relatif sama. Pada perjalanan tugas pertumbuhan dan perkembangan manusia akan dihadapkan pada masalah kesehatan, masalah sakit dan penyakit. Pada kondisi sakit individu dihadapkan pada 
masalah gangguan fisik yang berdampak gangguan yang lainnya seperti gangguan psikologis, gangguan spiritual dan lainnya.

Masalah kesehatan akan selalu menjadi isue yang dominan dalam perjalanan kehidupan sampai berakhirnya siklus kehidupan manusia. Masalah kesehatan yang paling sering di rasakan akhir-akhir ini adalah masalah penyakit kronis yaitu penyakit Diabetes Millitus. Penyakit diabetes militus adalah penyakit kronis yang dapat menimbulkan stress, Reiss (1986). Diabetes adalah salah satu gangguan kesehatan yang bersifat kronis dan paling berdampak psikologis pada pasien dan sering dikaitkan dengan dengan beberapa gangguan kejiwaan. Pasien dengan diabetes dua kali lebih beresiko memiliki status kecemasan,depresi dan masalah psikologis yang serius. Tekanan emosional pasien secara langsung dapat mempengaruhi hasil pengobatan mencakup kontrol glikemi dan komplikasi yang timbul. Kepatuhan terhadap pengobatan, tingginya biaya pengobatan juga menjadi faktor yang menjadikan tekanan psikologis pasien. (Najmeh, 2014)

Tekanan psikologis pasien yang mengalami diabetes militus sering dikaitkan dengan kesejahteraan spiritual dan kepatuhan religus. Penelitian yang dilakukan oleh Najmeh,2014 yang berjudul Spiritual Well-Being and Quality of Life of Iranian Adults with Type 2 Diabetes, menyebutkan bahwa kualitas kesejahteraan spiritual yang buruk paling banyak menyebabkan pasien jatuh pada kondisi depresi. Kondisi gangguan ini pada akhirnya akan mempengaruhi kualitas hidup pasien. Sangat penting perhatian kita pada penanganan spiritualitas dan religiusitas dalam manajemen diabetes militus. Beberapa penelitian menunjukan bahwa terdapat hubungan yang positif antara kesejahteraan spiritual dengan manajemen diabetes seperti kontrol glikemi dan manajemen diri.

Sebuah survei dengan melakukan wawancara pada 70 penderita diabetes militus tipe 2 di daerah Afrika menyimpulkan bahwa tema paling dominan dan paling konsisten yang muncul pada kelompok khusus ini adalah spiritualitas sebagai faktor penting dalam kesehatan umum, penyesuaian penyakit dan mengatasi penyakit. Temuan ini menunjukan bahwa perilaku pengelolaan penyakit diabetes militus dapat menjadi optimal apabila dipahami dari sudut pandang konteks sosial budaya dan keluarga. Pengaruh spiritualitas menjadi sangat penting dalam pelaksanaan intervensi yang bertujuan meningkatkan pengelolaan diri dan mengurangi dampak psikologis dari penyakit diabetes. (Samuel \& Hodge, 2000)

Terbatasnya informasi yang berkaitan dengan spiritualitas pasien dan keluarga serta adanya pandangan yang berbeda dalam menafsirkan spiritualitas dan religiusitas menjadikan kurang optimal dalam meningkatkan kesejahteraan spiritual pasien yang pada akhirnya dapat membantu pasien 
meningkat kualitas hidupnya. Bagaimana sebenarnya konsep spirituality dan religion itu dalam konteks keperawatan pasien dengan diabetes militus tipe-2 akan dibahas pada artikel berikut ini.

\section{PEMBAHASAN}

Pembahasan artikel ini lebih ditekankan kepada konsep kesejahteraan spiritual dan religiusitas sehingga tidak membahas patologi penyakit diabetes militus tipe 2. Sebelum menjelaskan kesejahteraan spiritual dalam konteks keperawatan keluarga dengan diabetes militus terlebih dahulu perlu dijelaskan konsep religion dan konsep spirituality. Beberapa pengertian yang diajukan untuk menjelaskan religion antara lain adalah sebagai berikut ;

Religion refers to a set of variously organized beliefs about the relationship between natural and supernatural aspects of reality, and about the role of humans in this relationship.While religion is difficult to define, one standard model of religion, used in religious studies courses, was proposed by Clifford Geertz, who simply called it a "cultural system" (Clifford, 1973)

Religion/agama mengacu pada satu set berbagai keyakinan yang terorganisir tentang hubungan antara alam dan aspek supranatural dari realitas, dan tentang peran manusia dalam hubungan ini. (Clifford Geertz, 1973). Konsep religion memiliki narasi, simbol, dan sejarah suci yang dimaksudkan untuk menjelaskan makna hidup dan / atau untuk menjelaskan asal usul kehidupan atau alam semesta. Dari keyakinan mereka tentang alam semesta, sifat manusia, asal usul kejadian manusia dan sistem moralitas, etika, hukum agama atau gaya hidup.

Ada banyak agama di dunia, diperkirakan lebih dari empat ribu agama ada di dunia, dan masingmasing agama tersebut memiliki kitab suci, tempat-tempat suci, kegiatan ritual, khotbah, peringatan, pemujaan dan pengorbanan. Agama juga mengatur perilaku yang diharapkan dan terorganisir dengan rapi, memiliki tokoh-tokoh agama yang dipatuhi, praktek agama juga dapat mencakup upacara dan pemakaman jenazah, tata cara pernikahan, meditasi, doa, musik, seni, tari, layanan publik. Beberapa agama mungkin muncul karena faktor kebudayaan dan karena aspek mythology.

Demikian kurang lebih penjelasan tentang religion sebagai pengantar sebelum menjelaskan tentang spirituality, sehingga dapat memberikan kejelasan perbedaan konsep atau persepsi pemahaman yang lebih mendalam tentang spirituality dalam konteks masalah yang kita pelajari.

Spiritualitas dapat dijelaskan dalam banyak cara dan telah dapat dibedakan dengan religiusitas dimana religiusitas lebih mencerminkan individu terhadap ketaatan terhadap perintah dari luar dan 
sangat terkait dengan tradisi iman tertentu, sedangkan spiritualitas lebih dari pengalaman batin, Sinnot,1998 dalam (Cartwright, 2001).

Spiritualitas adalah konsep yang luas dengan berbagai dimensi dan perspektif yang ditandai adanya perasaan keterikatan (koneksitas) kepada sesuatu yang lebih besar dari diri kita, yang disertai dengan usaha pencarian makna dalam hidup atau dapat dijelaskan sebagai pengalaman yang bersifat universal dan menyentuh. Beberapa individu menggambarkan spiritualitas dalam pengalampengalaman hidupnya seperti adanya perasaan terhubung/transendental yang suci dan menentramkan, sebagaian individu yang lain merasaan kedamaian saat berada di masjid, gereja, kuil atau tempat suci lainnya.

Beberapa ahli memberikan definisi tentang spiritualitas dengan pendekatan yang berbeda-beda berpendapat bahwa spiritualitas adalah aspek kemanusiaan yang mengacu pada cara individu mencari dan makna tersurat dan tujuan dan cara mereka mengalami keterhubungan mereka untuk saat ini, untuk diri, orang lain, dengan alam, dan dengan kebermaknaan atau suci (Christina Puchalski, MD, Director of the George Washington Institute for Spirituality and Health)

Menurut Mario Beauregard and Denyse O'Leary, researchers and authors of The Spiritual Brain berpendapat bahwa Spiritualitas berarti pengalaman yang berpikir untuk membawa mengalaminya ke dalam kontak dengan Tuhan (dengan kata lain, bukan hanya pengalaman yang terasa bermakna). Ruth Beckmann Murray dan Judith Proctor menulis bahwa dimensi spiritual mencoba untuk menjadi selaras dengan alam semesta, dan berusaha untuk jawaban tentang yang tak terbatas, dan datang ke dalam fokus ketika seseorang menghadapi stres emosional, penyakit fisik, atau kematian. (Krentzman, 2013)

Delgado (2002), mengidentifikasi empat karakteristik spiritualitas yang dianggap penting ; 1) Spiritualitas memerlukan sistem kepercayaan (kemauan untuk percaya) dan apa yang diyakini sebagai kebenaran ( keyakinan ada kekuatan yang lebih tinggi atau adanya agama berdasarkan keyakinan inti), 2) Spiritualitas melibatkan kondisi individu dalam pencarian makna dan tujuan keterikatan transenden atau misi individu yang merasakan terpanggil karena takdir atau nasib dan bergeser dari nilai-nilai material kepada nilai-nilai idealis, 3) Spiritualitas meliputi kesadaran keterikatan dengan orang lain yang didapatkan melalui instropeksi diri. Dalam konteks non religion, kondisi ini dapat dijelaskan sebagai rasa kagum, apresiasi dan rasa hormat. Dalam konteks agama, itu termasuk hubungan yang tinggi dengan Tuhannya yang di hubungkan dengan doa dan meditasi. Spiritualitas melibatkan proses rekonsiliasi keyakinan dan praktek pada saat individu dihadapkan pada kesulitan dan kondisi sakit, 4) Spiritualitas adalah kepercayaan bahwa seseorang dapat 
melampaui batas dirinya dalam dimensi yang lebih tinggi, adanya keinginan untuk sebuah kebenaran dan kesucian dan keyakinan bahwa seseorang dapat menyelesaikan kesulitan,kerugian dan rasa sakit dengan kepercayaan tersebut. (Hanna, 2006)

Lebih lanjut Delgado dijelaskan bahwa, selain empat karakteristik tersebut, ada beberapa manfaat yang dirasakan dari keterikatan spiritual (spiritual connections) yaitu ; 1) Meningkatkan perasaan akan kedamaian diri dan kekuatan batin, meningkatkan kesadaran pribadi, penerimaan yang baik tentang kehidupan dunia, kemampuan untuk mengatasi ketidakpastian hidup dan ambiguisitas, kemampuan menerima kondisi seperti kemerosotan fisik karena usia, kondisi sakit terminal dan keadaan stres. 2) Kemampuan beradaptasi dengan baik (successful adaptation) dan pemulihan kesehatan bersama dengan harmoni alam sangat diperlukan untuk kesehatan. Upaya lain adalah melalui restorasi doa dengan tuhan sebagai perantara perjanjian dengan tuhannya sehingga dapat diberikan kesehatan.

Henery (2003, seperti dalam Delgado,2005) mengidentifikasi tiga asumsi tentang spiritualitas ; 1) Spiritualitas semakin penting untuk teori dan praktek. 2) Spiritualitas biasanya di anggap bagian dari pasien. 3) Memenuhi kebutuhan spiritual pasien adalah membantu pasien mengatasi penderitaan (karena penyakit kronis) dan kehilangan. (Hanna, 2006)

Edvin Bru (2011), melakukan penelitian berkaitan penderitaan yang dialami pasien dewasa diabetes militus tipe-2 yang dihubungkan dengan beberapa variabel internal pasien yang berkaitan dengan spiritualitas antara lain gaya koping dan perasaan akan dukungan dibandingkan dengan indikator klinis, menunjukan bahwa faktor yang terbesar mempengaruhi penderitaan pasien diabetes millitus tipe-2 adalah kondisi internal pasien sebesar (40), dibanding dengan indikator klinis hanya $(5,8 \%)$. Penelitian ini membuktikan bahwa spiritualitas seseorang sangat menentukan keberhasilan penatalaksanaan penyakit-penyakit kronis. (Karlsen \& Bru, 2012).

Diabetes Militus tidak saja mengakibatkan kerusakan kondisi fisik pasien, tetapi juga mengancam kondisi kehidupan sosial, fungsional, dan kondisi kesehatan emosional dari pasien. Kondisi ini menyebabkan pasien merenung dan menanyakan kondisi pada dirinya sendiri tentang makna dan tujuan hidup mereka. Diabetes dapat mengerahkan dampak negatif pada kualitas hidup karena diabetes adalah penyakit kronis seumur hidup, pasien diabetes harus berurusan dengan penyakit mereka sepanjang hari. Terapi medis, komplikasi diabetes, episode hipoglikemia, dan adanya kecemasan dan ketakutan konsekuensi jangka panjang dapat menyebabkan penurunan kualitas hidup (Najmeh,2014) 
Hubungan spiritualitas dengan keadaan pasien diabetes militus kita sebut dengan istilah peran spiritualitas (the role of spirituality). Peran spiritualitas dapat di jelaskan dalam konteks keyakinan yang dieksplorasikan pada konsep keimanan. Dalam hal ini menjadi penting untuk mempelajari istilah iman, tuhan,cobaan,rasa syukur dan nikmat sesuai keyakinan pasien. Hal lain yang juga penting adalah sarana dan prasarana penunjang praktek keimanan seperti tempat ibadah dan kitab suci yang digunakan pasien. Istilah-istilah tersebut berkaitan erat dengan peran spiritualitas dalam memberikan kontribusi positif maupun dampak negatif dalam hal status kesehatan, kepuasan hidup, dukungan sosial, teknik mengatasi masalah, dan manajemen stres. (Samuel \& Hodge, 2000)

Peran konsep Tuhan bagi penderita diabetes sangat menentukan kondisi psikologis pasien berkaitan dengan asal usul penyakit dan ketentuaan Tuhan, konsep ini memberikan ketenangan bagi pasien bila selalu mengkaitkan bahwa kondisi yang dialami tidak bisa lepas dari kentutan tuhan dan penyakit akan menjadi lebih baik karena kehendak dan ketetapan tuhan. Penelitian yang dilakukan oleh Samuel 2000, menyebutkan bahwa beberapa responden menyebutkan "Allah" dalam konteks kondisi status kesehatan yang mereka rasakan dengan mengucapkan terima kasih kepada Tuhan atas kesehatan mereka bahkan responden yang menderita diabetes merasakan tenang dalam merawat diabetes mereka (terutama untuk pengobatan penyakit tanpa harus menggunakan insulin). Spiritualitas adalah tema utama dalam semua kelompok fokus. Peserta melaporkan bahwa Allah memainkan peran sentral dalam memberikan kekuatan untuk menghadapi tantangan sehari-hari, termasuk yang berhubungan dengan diabetes. Spiritualitas mereka terlihat sebagai sumber dukungan emosional, pengaruh positif pada kesehatan, dan berkontribusi terhadap kualitas hidup.

Hal ini sejalan dengan pendapat (Hana,2006) yang menyebutkan spiritualitas adalah kepercayaan bahwa seseorang dapat melampaui batas dirinya dalam dimensi yang lebih tinggi (dengan tuhannya), adanya keinginan untuk sebuah kebenaran dan kesucian dan keyakinan bahwa seseorang dapat menyelesaikan kesulitan,kerugian dan rasa sakit dengan kepercayaan tersebut

Tempat ibadah, dapat memberikan nuasa ketenangan dan kebahagian psikologis bagi pasien saat menyampaikan pengharapan-pengharapan atau saat seseorang merasakan dimensi yang berbeda berada di tempat yang dianggapnya suci atau hanya sekedar menenangkan diri, bagi individu yang lain menjadi pengurus dan berpartisipasi dalam kegiatan peribadatan meningkatkan keyakinan bahwa tuhan akan memperhatikan setiap individu yang memperhatikan tempat suci sesuai agamanya. Hal ini sejalan dengan pendapat Delgado (2002) yang menyebutkan bahwa kemampuan beradaptasi dengan baik ( successful adaptation) dan pemulihan kesehatan melalui restorasi doa dengan tuhan sebagai perantara perjanjian dengan tuhannya sehingga dapat diberikan kesehatan. 
Membaca kitab suci, merupakan salah satu sarana berkomunikasi dengan Tuhannya atau dengan kekuatan yang dianggap diatas kekuatan yang lain merupakan bagian dari strategi yang digunakan untuk mengatasi tekanan dan perasaan menderita karena penyakit yang dideritanya. Sebagian keyakinan mempercayai bahwa membaca kitab suci dapat menyembuhkan dan meringankan penderitaan.

Dalam kontek keperawatan, perbedaan spiritualitas dan religiusitas dapat dijelaskan dengan memahami konsep tersebut dalam pendekatan masalah keperawatan, spiritualitas dan religiusitas berada pada kompartemen yang sama yaitu domain prinsip hidup dan berada pada kelas keyakinan dan keselarasan nilai. Spiritualitas dalam kontek masalah keperawatan mempunyai tiga jenis diagnosa keperaawatan yaitu ; 1) Kesiapan Meningkatkan Kesejahteraan Spiritual, 2) Distres Spirituan dan, 3) Resiko Distres Spiritual. Religiusitas dalam kontek masalah keperawatan mempunyai tiga jenis diagnosa keperawatan yaitu ; 1) Hambatan Religiusitas, 2) Kesiapan Meningkatkan Religiusitas dan Resiko Hambatan Religiusitas. (NANDA, 2012)

Perbedaan masalah keperawatan spiritualitas dan religiusitas pada pasien diabetes militus tipe-2 diarahkan pada bagaimana perawat memahami konsep tersebut sehingga dapat membedakan inventarisasi data-data spesifik dari pasien dan perawat dapat menyimpulkan secara tepat masalah apa yang sedang di hadapi pasien apakah masalah spiritualitas atau masalah religiusitas. Berikut salah satu contoh bagaimana perawat membedakan masalah spiritualitas dan religiusitas.

Kesiapan Meningkatkan Kesejahteraan Spiritual, adalah pola yang dapat dikembangkan dimiliki individu pada saat mengalami dan berusaha mengintegrasikan makna dan tujuan hidup melalui hubungan dengan diri sendiri,orang lain,seni,musik,literatur,alam,dan/atau kekuatan yang lebih besar dari pada diri sendiri. Pasien diabetes militus dengan pehaman yang baik akan kondisi sakit yang bersifat kronis dan memerlukan perawatan yang panjang akan mengungkapkan penerimaan tentang penyakitnya, meningkatnya keinginannya akan harapan kesejahteraan dalam kondisi sakitnya, serta mengungkapkan tentang makna dari sakit dan tujuan hidupnya adalah merupakan data-data yang akurat untuk masalah ini. Data lain yang munkin ada adalah adanya keinginan pasien untuk tetap ditemani orang terdekat, tokoh agama/spiritual, mendengarkan musik yang menentramkan, berdoa dan mengungkapkan kekaguman akan dzat yang maha agung.

Kesiapan Meningkatkan Religiusitas, adalah kemampuan individu untuk meningkatkan kebergantuan pada keyakinan agama dan/atau berpartisipasi dalam ritual tradisi kepercayaan tertentu. Pasien diabetes militus dengan pehaman yang baik akan kondisi sakit yang bersifat kronis dan memerlukan perawatan yang panjang akan mengungkapkan keinginan memperkuat keyakinan agamanya yang 
dapat memberikan kenyamanan, meminta bantuan untuk meningkatkan partisipasi dalam keyakinan agama yang diprogramkan seperti ritual,ibadah, perayaan keagamanan, berdoa dan yang lainnya.

Dari contoh dua masalah keperawatan tentang spiritualitas dan religiusitas dapatlah dibedakan bagaimana pasien diabetes yang mengalami masalah spiritualitas dan pasien yang mengalami maslah religiusitas, karena keduanya memiliki konsep dan dimensi yang berbeda.

\section{SIMPULAN DAN IMPLIKASI PENELITIAN}

Religiusitas mengacu pada satu set berbagai keyakinan yang terorganisir tentang hubungan antara alam dan aspek supranatural dari realitas, dan tentang peran manusia dalam hubungan ini.

Spiritualitas adalah konsep yang luas dengan berbagai dimensi dan perspektif yang ditandai adanya perasaan keterikatan (koneksitas) kepada sesuatu yang lebih besar dari diri kita, yang disertai dengan usaha pencarian makna dalam hidup atau dapat dijelaskan sebagai pengalaman yang bersifat universal dan menyentuh.

Diabetes dapat mengerahkan dampak negatif pada kualitas hidup karena diabetes adalah penyakit kronis seumur hidup, pasien diabetes harus berurusan dengan penyakit mereka sepanjang hari.

Perbedaan masalah keperawatan spiritualitas dan religiusitas pada pasien diabetes militus tipe-2 diarahkan pada bagaimana perawat memahami konsep spiritualitas dan religiusitas

\section{DAFTAR PUSTAKA}

Cartwright, K. B. (2001). Cognitive Developmental Theory and Spiritual Development. Journal of Adult Development, Volume 8.

Chesla, C. A., \& Fisher, L. (2010). Family and Disease Management in African-American Patients With Type 2 Diabetes. San Francisco: Departement of Family Health Care Nursing, University of California.

Clifford, G. (1973). Interpretation Of Cultures. Dalam Basic Books (hal. 87). New York: Inc,Publishers.

Hanna, H. H. (2006). THE INFLUENCE OF SELF-EFFICACY AND SPIRITUALITY ON SELF-CARE BEHAVIORS AND GLYCEMIC CONTROL IN OLDER AFRICAN AMERICANS WITH TYPE 2 DIABETES. ProQuest Information and Learning Compant , 22-24.

Karlsen, B., \& Bru, E. (2012). The relationship between clinical indikators, coping styles, perceived support and diabetes-realted distress among adults with type 2 diabetes. Journal of Advenced Nursing , 391-401. 
Krentzman, A. R. (2013). What Is Spirituality. Takingcharge.csh.umn.edu .

Najmeh, J. (2014). Spiritual Well-Being and Quality of Life of Iranian Adults with Type 2 Diabetes . Evidence-Based Complementary and alternative medicine , 1-8.

NANDA. (2012). Nursing Diagnoses : Definitions \& Classification 2012 - 2014. Dalam H. T. Herdman, Nursing Diagnoses : Definitions \& Classification (hal. 501-525). Jakarta: EGC.

Samuel, \& Hodge. (2000). Influences on day to day self-management of type-2 diabetes. Proquest Nursing \& Allied Health Source , 7 . 